\title{
Metacognitive Behaviour of Malaysian Students While Solving Mathematical Problems of Form Three Assessment (PT3)
}

\author{
Comportamento Metacognitivo Dos Estudantes Da Malásia Ao Resolver \\ Problemas Matemáticos Da Avaliação Do Formulário Três (PT3)
}

\author{
Abdul Halim Abdullah* \\ Surya 'Ain Ahmed"* \\ Sharifah Nurarfah S. Abd Rahman ${ }^{* * *}$ \\ Soh Hon Mun ${ }^{* * * *}$ \\ Mahani Mokhtar ${ }^{* * * * *}$
}

\begin{abstract}
Several studies on metacognition have sought to solve mathematical problems. However, in Malaysia, there has yet to be a study investigating the metacognitive behaviour of students in solving mathematical problems of Form Three Assessment (Pentaksiran Tingkatan Tiga - PT3). This study was conducted to identify the metacognitive behaviour of students while solving mathematical problems in PT3 and examine differences in metacognitive behaviour among successful students (SS), partially successful students (PSS), and unsuccessful students (USS). A total of six (6) Form Three students in a school in Johor Bahru participated in this study. The research instrument used was the actual set of 2014's PT3 questions. Data were analysed using the Thinking Aloud method with reference to Foong's Taxonomy (1993), and it was supported by analysis of the students' written work. Results showed seven types of metacognitive behaviour exhibited by the students, depending on the types of questions given. The analysis also found that each category of students showed different types of metacognitive behaviour while solving their PT3 mathematical problems. The SS group could control their metacognitive behaviour in mathematical problem-solving more regularly and frequently, the PSS students behaved moderately, while the USS group demonstrated limited metacognitive behaviour. As the results indicated differences in metacognitive behaviour among students of different performance levels, teachers should help students with weakness in solving mathematical problems implement metacognitive behaviour to strengthen their mathematical proficiency.
\end{abstract}

Keywords: Metacognitive Behaviour. Mathematical Problem Solving. Form Three Assessment (PT3).

\footnotetext{
* Faculty of Education, Universiti Teknologi Malaysia (UTM), 81310 Johor Bahru, Malaysia. E-mail: phalim@utm.my.

** Faculty of Education, Universiti Teknologi Malaysia (UTM), 81310 Johor Bahru, Malaysia. E-mail: suryaain1711@gmail.com.

${ }^{* * *}$ Faculty of Education, Universiti Teknologi Malaysia (UTM), 81310 Johor Bahru, Malaysia. E-mail: snurarfah6391@gmail.com.

**** Faculty of Education, Universiti Teknologi Malaysia (UTM), 81310 Johor Bahru, Malaysia. E-mail: munmun1103@gmail.com.

${ }^{* * * * *}$ Faculty of Education, Universiti Teknologi Malaysia (UTM), 81310 Johor Bahru, Malaysia. E-mail: pmahani@utm.my.
} 


\section{Resumo}

Vários estudos sobre metacognição procuraram resolver problemas matemáticos. Assim, na Malásia, existe um estudo investigando o comportamento metacognitivo dos alunos na resolução de problemas matemáticos da Avaliação do Ensino Médio (Pentaksiran Tingkatan Tiga - PT3). Esse estudo foi realizado para identificar o comportamento metacognitivo dos estudantes quanto à resolução de problemas matemáticos no PT3 e analisar as diferenças no comportamento metacognitivo entre os estudantes bem sucedidos (SS), estudantes parcialmente bem sucedidos (PSS) e estudantes não aprovados (USS). Um total de seis (6) estudantes do Ensino Médio em uma escola de Johor Bahru participaram desse estudo. O instrumento de investigação usado foi o conjunto de perguntas do PT3 de 2014. Os dados foram analisados usando o método Thinking Aloud com referência a Taxonomia de Foong (1993) e tendo como suporte a análise do trabalho escrito dos estudantes. Os resultados demonstraram sete tipos de comportamento metacognitivo exibido pelos estudantes, dependendo dos tipos determinados de perguntas. A análise também concluiu que cada categoria de estudantes evidenciou tipos diferentes de comportamento metacognitivo quanto à resolução dos problemas matemáticos de seus PT3. O grupo SS conseguiu controlar seu comportamento metacognitivo na resolução do problema matemático mais regularmente e com mais frequência, o PSS se comportou moderadamente, enquanto o grupo USS demonstrou um comportamento metacognitivo limitado. Como os resultados indicaram diferenças no comportamento metacognitivo entre os estudantes de níveis de desempenho diferentes, os professores deverão ajudar os estudantes com dificuldade em resolver os problemas matemáticos implementando o comportamento metacognitivo para reforçar a proficiência matemática dos mesmos.

Palavras-chave: Comportamento Metacognitivo. Resolução de Problemas Matemáticos. Avaliação Ensino Médio (PT3).

\section{Introduction}

Mathematics is a universal subject as it deals with learning numbers and has extensive applications in daily living. The applications of mathematics are evident in various subjects taught at universities such as the topic of Integration in Calculus, the importance of algebra in computer science and networking systems, as well as trigonometry's fundamental theories needed when studying astronomy (Yeong, 2010). Although problem-solving is an important skill in learning mathematics, Malaysian students are still weak in mastering this skill (Abdullah et al., 2014). A report released by Trends in International Mathematics Science Study (TIMSS) in 2007 showed that Malaysian participants did not produce impressive results in cognitive dimension and demonstrated poor performance in problem-solving and thinking skills. The report indicated that Malaysian students could not answer questions requiring higher-order thinking (Ministry of Education, 2012). The National Council of Teachers of Mathematics (2000) explained that teaching through the method of problembased learning is about "solving problems in an interesting manner" and, therefore, needs to be widely applied by teachers. Educators of mathematics regard problem-solving as a heuristic process (Polya, 1945), logic-based programme (Newell \& Simon, 1972), a method of inductive and deductive discovery (Lakatos, 1976), a framework for goal-oriented decision-making (Schoenfeld, 1985), a standard matter (NCTM, 2000), and activities which 
utilise models (Lesh \& Zawojewski, 2007). Mayer (1985; 1987) recommended four types of processes or information needed in solving mathematical problems, namely interpretation, integration, planning and observation, as well as the execution of solutions. Zaidatun (2007) argued that to solve problems one needs to go through the planning, observation, and evaluation stages, i.e., the skills involved in one's metacognitive process. Flavell (1979) defined metacognition as one's knowledge, which involves consideration of thinking processes and cognitive products, active monitoring, regular arrangements, as well as the assessment of cognitive activities. Whereas according to Schoenfeld (1985), metacognition is a form of regulation towards cognitive activity and a mechanism form for students to decide when, how, and whether they will use mathematical facts and procedures they have in order to plan, monitor, and check the activities. Moreover, Flavell et al. (2002) stated that metacognition is 'thinking about thinking' or 'cognition about cognition'. Metacognitive behaviors refer to regulation of cognitive activities in problem solving. The metacognitive behavior in this study was based on the seven types of behavior which were observed using Foong Taxonomy (1993) as shown in Table 1.

\section{The emphasis on Higher-Order Thinking Skills (HOTS) in Form Three Assessment}

According to Abdullah and Effandi (2013) and Effandi et al. (2010), mathematics achievement is often a topic of discussion among those who are involved in education, in particular on the issue of variations in students' achievements in examinations such as the Lower Secondary Assessment (Penilaian Menengah Rendah - PMR) and the Malaysian Education Certificate (Sijil Pelajaran Malaysia - SPM). Results from the examinations are not encouraging. Ahmad and Azwawi (2006) stated that mathematics achievement in PMR showed a small percentage of fluctuation from year to year. This finding affects the enrolment of students in the science stream since the achievement of Mathematics in Lower Secondary Assessment will determine the number of students in the science stream at the SPM level. Malaysia's Education Blueprint, which launched in 2012, has outlined that, starting 2014, students across the country would be equipped with higher-order thinking skills (HOTS), delivered to them by teachers through classroom teaching, extracurricular activities, and examinations. This plan is implemented under Malaysia's Education Development Master Plan, which aims to produce students who possess a high level of thinking skills and can compete internationally. In this case, the Ministry of Education (MOE) will systematically increase the number of HOTS questions in school-based assessments and public 
examinations. These questions are constructed based on Bloom's Taxonomy, and they test skills such as the abilities to apply, analyse, evaluate, and create. By 2016, questions which assess these skills will make up $80 \%$ of UPSR questions, $80 \%$ of Form Three Assessment questions, and 75\% of SPM's core subjects questions, and 50\% of SPM's elective subjects questions.

\section{The importance of metacognition in solving mathematical problems}

This is an important study because students have different patterns of problem-solving, although they demonstrate few similarities such as reading given problems, analysing information, planning steps, as well as calculating and checking answers (Wong and Abdullah, 2009). Kazemi et al. (2010) stated that metacognition is important in helping students to solve mathematical problems accurately. Also, Rompayom et al. (2010) described that metacognition is vital in the students' learning process because it could encourage them to correlate what they learned in mathematics with their experiences in reality. Vrugt \& Oort (2008), Trainin \& Swanson (2005), and Otero, Campanario \& Hopkins (1992) reported that the use of metacognitive strategies would influence the performance of students in problemsolving processes. They found that students who often use metacognitive strategies performed better at their tasks, and vice versa. These findings echo those in Abdullah et al. (2017) in Malaysia, in which students with a very high performance level were directly proportional to the metacognitive skills.

\section{Research objective}

This study aims to examine differences in metacognitive behaviour when solving PT3 mathematical problems among SMK Tun Perak successful, partially successful, and unsuccessful students. PT3 is a summative assessment at lower secondary education level, which is used to view the academic achievement of students. PT3 has been implemented since April 1, 2014 to replace the Lower Secondary Assessment (PMR) and therefore the examination format differs. PT3 contains more HOTS questions as compared to PMR. Furthermore, PT3 contains subjective questions as opposed to PMR questions, which are objective, and there is a slight change in difficulty ratio from 5:3:2 for PMR to 3:4:3 for PT3 (Easy: Moderate: Difficult). 


\section{Research methodology}

This research adopted a qualitative method and used Polya's Problem Solving Techniques (1957) as a framework. The framework comprises the process of understanding a problem, designing a suitable problem-solving method, and implementing and reviewing solutions to conclude with correct answers. The research respondents consisted of six Form Three students who obtained good results in their mid-year tests. They were selected through purposive sampling. The respondents performed well in mathematics, possessed a high interest in the subject, and were able to offer their opinion while solving the mathematical problems assigned to them. This study required the respondents to solve one non-routine and problem-based mathematics problem from the 2014 PT3 Mathematics examination paper (see Figure 1). The questions were selected because they met the characteristics of nonroutine mathematical questions as listed below:

i. require higher order thinking skills

ii. can improve reasoning skills

iii. answers and procedures to be used are not immediately clear

iv. there is more than one solution and strategy

v. capable of producing students who are creative and innovative

vi. there is more than one answer and the solution requires more than deciding and choosing Mathematical operations

\begin{tabular}{|c|c|c|}
\hline \multicolumn{3}{|c|}{$\begin{array}{l}\text { 1. Table 1(a) shows dividend received by Fatin from her investment. } \\
\text { Jadual } 1 \text { (a) menunjukkan dividen yang diterima oleh Fatin daripada hasil } \\
\text { pelaburannya. }\end{array}$} \\
\hline $\begin{array}{c}\text { Types of } \\
\text { Investments } \\
\text { Jenis pelaburan }\end{array}$ & $\begin{array}{c}\text { Total of } \\
\text { Investment } \\
\text { Jumlah pelaburan } \\
\text { (RM) } \\
\end{array}$ & $\begin{array}{c}\text { Dividend } \\
\text { Percentage } \\
\text { Peratusan Dividen }\end{array}$ \\
\hline ASB & 1000 & $35 \%$ \\
\hline ASN & 3500 & $4 \%$ \\
\hline \multicolumn{3}{|c|}{$\begin{array}{l}\text { Table 1(a) } \\
\text { Jadual 1(a) }\end{array}$} \\
\hline \multirow{2}{*}{\multicolumn{3}{|c|}{$\begin{array}{l}\text { Fatin reinvest RM } 102 \text { from the total dividens she received into ASB investment. } \\
\text { What is the remaining percentage that she did not use in her reinvestment? } \\
\text { Fatin melabur semula sebanyak RM102 daripadajumlah dividen yang diterimanya ke dalam } \\
\text { pelaburan ASB. Berapakah peratusan baki daripada jumlah dividennya yang tidak } \\
\text { dilaburkan semula? }\end{array}$}} \\
\hline & & \\
\hline & & $\begin{array}{r}\text { (3 marks) } \\
\text { (3 markah) }\end{array}$ \\
\hline
\end{tabular}

Figure 1 - One of the PT3 Mathematics Questions Source: 2014 PT3 Examination Paper 
The 'thinking aloud protocol' was conducted on every respondent, who were seated separately to prevent discussions between the respondents. This arrangement would prevent or reduce bias in the data collection process. Abdullah (2009) argued that 'thinking expression' is more secure and reliable than other oral statement methods. The issues of validity and reliability of this approach had already been widely discussed by previous empirical studies such as Ericsson and Simon (1993) and Crisp (2008). One mutual conclusion was that there is a close relationship between behaviour and verbal skills, if appropriate techniques were used and if they were paralleled with given directions. For instance, instead of giving verbal responses, the respondents were asked to write their thoughts. Researchers also have the opportunity to probe during long pauses.

Table 1 illustrates the metacognitive behaviour which may occur during a mathematical problem-solving activity. The mathematics problem used in this study was taken from the 2014 PT3 paper. The data were analysed using the coding scheme in Foong's Taxonomy (1993). For the purpose of discussion, students were categorised differently, and they were represented by SS (successful students), PSS (partially successful students), and USS (unsuccessful students).

Table 1 - Coding Scheme of Foong's Taxonomy (1993)

\begin{tabular}{|l|l|}
\hline M-Category & Metacognition \\
& M1 - Proposing Plans \\
& M2 - Identifying the Level of Question (Easy or Difficult) \\
& M3 - Re-examining the Development \\
& M4 - Identifying Mistakes \\
& M5 - Identifying New Knowledge \\
& Q1 - Asking Relevant Questions \\
& N1 - Being Rhetoric on Tasks that are Irrelevant with Words \\
\hline
\end{tabular}

Source: Foong (1993)

\section{Results}

\subsection{The analysis of metacognitive behaviour differences in PT3 mathematical problem- solving among successful students, partially successful students, and unsuccessful students.}

An analysis was carried out using the 'thinking aloud protocol' and the results of a written survey gave answers to the following research question: What are the metacognitive behaviour differences among different categories of students, namely successful students, partially successful students, and unsuccessful students regarding solving PT3 mathematical 
problems? Past studies showed that there was a clear difference between successful, less successful, and unsuccessful students during the problem-solving process. However, until now, there has been no study focusing on problem-solving in PT3's Mathematics subject.

To determine the differences between the metacognitive behaviour of students in these three different categories, the researcher used the z-score's stem-fiz score range. Table 2 describes the determination of the application level of students' metacognitive behaviour in solving PT3 mathematical problems.

Table 2-Determination of the Level of Application of Students' Metacognitive Behaviour in Solving PT3 Mathematical Problem

\begin{tabular}{|c|c|c|c|c|c|}
\hline STUDENT & SCORE & Z-SCORE & T-SCORE & LEVEL & CATEGORY \\
\hline 1.0 & 83.3 & 1.23009830 & 62.300983 & Very High & Successful \\
\hline 2.0 & 80.0 & 1.10213140 & 61.021314 & Very High & Successful \\
\hline 3.0 & 50.0 & -0.06120440 & 49.387956 & Moderate & Partially Successful \\
\hline 4.0 & 42.0 & -0.37142730 & 46.285727 & Moderate & Partially Successful \\
\hline 5.0 & 37.5 & -0.54592761 & 44.5407239 & Low & Unsuccessful \\
\hline 6.0 & 16.67 & -1.35367040 & 36.463296 & Very Low & Unsuccessful \\
\hline
\end{tabular}

Source: Research Data

\subsubsection{Proposing plans (M1)}

The SS group demonstrated strong M1 metacognitive behaviour. This behaviour was exhibited during the planning stage, where the SS reread the question given to extract important content and to determine the next steps to be taken. Table 3 shows the protocol used by participants when proposing plans (M1).

Table 3 - Verbal Protocol of Successful Students

\begin{tabular}{|c|c|c|c|}
\hline Participants & & Participant 1 & Participant 2 \\
\hline Verbal Protocol & $\begin{array}{l}\text { S3: } \\
\text { S5: } \\
\text { S9: }\end{array}$ & $\begin{array}{l}\text { "At first, for ASB he will get } \\
35 \% \text { times a thousand." } \\
\text { "From ASN, he will get } 4 \% \\
\text { from } 3500 . " \\
\text { And then he asked, "...how } \\
\text { much percentage is left from the } \\
\text { dividend that had not been } \\
\text { reinvested?" }\end{array}$ & $\begin{array}{l}\text { S4: "Oh. Aaaaaa... Try to do it..." } \\
\text { S6: "Ok, we do the ASB." } \\
\text { S8: "And then with the ASN he got } 4 \% \\
\text { dividend." } \\
\text { S10: "Fatin has reinvested with a total } \\
\text { of } 102 \text { from the total dividend } \\
\text { that she received from the } \\
\text { investment. RM, the total } \\
\text { dividend that had not been } \\
\text { reinvested... it's total..." }\end{array}$ \\
\hline
\end{tabular}

Source: Research Data

As for the PSS group, we discovered that their pattern of M1 metacognitive behaviour was similar to that of the SS's M1 metacognitive behaviour. However, the students planned unrelated solutions for the questions. For example, Participants 3 and 4 stated their opinions as shown in Table 4.

Table 4 - Verbal Protocol of Partially Successful Students

\begin{tabular}{l|l|r} 
Participants & Participant 3 & Participant 4 \\
\hline
\end{tabular}




\begin{tabular}{|c|c|c|}
\hline Verbal Protocol & $\begin{array}{l}\mathrm{S} 2: \text { "Ok, at first, } 100 \% \text { minus } 35 \% \\
\text { equals to } 65 \% \text {. So } 65 \% \text { is the } \\
\text { balance." } \\
\text { S3: "This means that } 65 \% \text { times } 102 \\
\text { equals } 66.3 ., \\
\text { S17: "This means that } 102 \text { over } 1000 \\
\text { times } 100 . " \\
\text { S22: "Then, the balance percentage... } \\
\text { 102 plus } 350 \text { over } 1000 . "\end{array}$ & $\begin{array}{l}\text { S4: "Ok, so the question wants the } \\
\text { dividend that was not being } \\
\text { reinvested." } \\
\text { S7: "Ok, divide RM } 102 \text { by } 1000 \text {, and } \\
\text { then multiply it by } 35 \% \text {." }\end{array}$ \\
\hline
\end{tabular}

Source: Research Data

Subsequently, the USS group showed M1 metacognitive behaviour that was unrelated with the questions' requirements and was obviously incorrect. The verbal protocol is stated in Table 5 below.

Table 5 - Verbal Protocol of Unsuccessful Students

\begin{tabular}{|c|c|c|}
\hline Participants & \multicolumn{1}{|c|}{ Participant 5 } & Participant 6 \\
\hline Verbal Protocol & $\begin{array}{l}\text { S13: "Then, the dividend's percentage." } \\
\text { S20: "Then, dividend." } \\
\text { S21: "So, the percentage of the dividend } \\
\text { is the one missing." }\end{array}$ & $\begin{array}{c}\text { S14: "The percentage of balance means } \\
\text { it has to be deducted from the } \\
\text { original percentage." }\end{array}$ \\
\hline
\end{tabular}
Source: Research Data

Furthermore, the USS group did not focus on the relevant content in the questions. The students did not extract the main content correctly, and this showed in their cognitive protocol stated in Table 6 below.

Table 6 - Verbal Protocol of Unsuccessful Students

\begin{tabular}{|c|c|c|}
\hline Participants & Participant 5 & Participant 6 \\
\hline Verbal Protocol & S5: "The type of investment... He & S2: “1000 plus 102, 1102." \\
& invested a total of 1000 in the & S5: "1000 minus 102 is equal to 898. \\
& ASB. The percentage of dividend & 898 over 1000 times 100, \\
& is 5\%." & $89.8 \% . "$ \\
& S12: "1000 plus 102... equals 1102...” & \\
\hline
\end{tabular}

Source: Research Data

\subsubsection{Identifying the level of question (M2)}

The data showed that the SS group did not show M2 metacognitive behaviour while answering the questions, because they were confident in solving the mathematical problems. They did not show any signs of doubt or hesitation. However, the PSS participants demonstrated M2 metacognitive behaviour at the early stage of problem-solving. The protocol is shown in Table 7.

Table 7 - Verbal Protocol of Partially Successful Students

\begin{tabular}{|c|c|}
\hline Participant & Participant 4 \\
\hline Verbal Protocol & S1: “It's difficult..." \\
\hline & Source: Research Data
\end{tabular}


In contrast to the PSS group, the USS students showed M2 metacognitive behaviour at the end of the problem-solving process. When the students failed to answer the question, they started to argue about the question's level of difficulty. The verbal protocols are as follows.

Table 8 - Verbal Protocol of Unsuccessful Students

\begin{tabular}{|c|c|}
\hline Participant & Participant5 \\
\hline Verbal Protocol & $\begin{array}{c}\text { S38: “This is really difficult... I don't } \\
\text { understand...” }\end{array}$ \\
& S47: “Ok, now I understand.” \\
\hline & Source: Research Data
\end{tabular}

\subsubsection{Re-examining the development (M3)}

It was found that the SS group exhibited M3 metacognitive behaviour at the end of the problem-solving process. For instance after answering the given question, they would review their responses. The protocol is in Table 9.

Table 9 - Verbal Protocol of Successful Students

\begin{tabular}{|c|l|l|}
\hline Participants & \multicolumn{1}{|c|}{ Participant 1 } & \multicolumn{1}{|c|}{ Participant 2 } \\
\hline Verbal Protocol & S18: “This is correct already.” & S12: “O.K. RM 388.” \\
& S20: "O.K. this is correct...” & S13: “I think this is right.” \\
\hline
\end{tabular}

Source: Research Data

On the other hand, the PSS respondents showed a limited demonstration of M3 metacognitive behaviour. The protocol is shown in Table 10 .

Table 10 - Verbal Protocol of Partially Successful Students

\begin{tabular}{|l|c|}
\hline Participant & Participant 3 \\
\hline Verbal Protocol & S18: “Eh...Haa ... Maybe...” \\
\hline
\end{tabular}

The USS displayed M3 metacognitive behaviour at the middle and the end of the problem-solving process. The verbal protocol is shown in Table 11.

Table 11 - Verbal Protocol of Unsuccessful Students

\begin{tabular}{|c|l|c|}
\hline Participants & \multicolumn{1}{|c|}{ Participant 5 } & Participant 6 \\
\hline Verbal Protocol & $\begin{array}{l}\text { S27: “I didn't get it...” } \\
\text { S54: “Ok, done!” (While checking the } \\
\text { answer). }\end{array}$ & S18: O.K. Correct. \\
\hline
\end{tabular}

Source: Research Data

The USS group was still unable to solve the given problems correctly. After going through reviewing or re-examining process, the students deleted their answers and tried to make other cognitive activities such as the ones highlighted in the verbal protocol in Table 12. It contradicted the requirements of the questions.

Table 12 - Verbal Protocol (Cognitive) of Unsuccessful Students

\begin{tabular}{|c|l|}
\hline Participant & \multicolumn{1}{|c|}{ Participant 5 } \\
\hline Verbal Protocol & S32: “So, 102 ... Erm... Plus 3500.” \\
& S35: “102 plus 3500, 3602.” \\
\hline
\end{tabular}




\subsubsection{Identifying mistakes (M4)}

The data indicated that the SS group showed M4 metacognitive behaviour immediately after they got the answer to the given problem. After that, the students tried to correct it and managed to get the correct answer. The verbal protocol is in Table 13 below:

Table 13 - Verbal Protocol of Successful Student

\begin{tabular}{|c|l|}
\hline Participant & \multicolumn{1}{|c|}{ Participant 1 } \\
\hline Verbal Protocol & S12: “Wrong!" \\
& S13: "Wrong!" \\
& S15: "Eh, it's not!" \\
\hline & Source: Research Data
\end{tabular}

PSS students showed M4 metacognitive behaviour throughout the problem-solving process. Although they managed to identify errors at the beginning of the process and tried to make corrections, they still gave wrong answers. Table 14 shows the examples of the verbal protocol.

Table 14 - Verbal Protocol of Partially Successful Students

\begin{tabular}{|c|l|}
\hline Participant & Participant 3 \\
\hline Verbal Protocol & S4: "Wrong!" \\
& S9: "Eh wrong!" \\
& S11: "Wrong. Wrong!" \\
& S12: "Over 1000, also wrong." \\
& S14: "650 over 1102 times 100\%, uittt \\
wrong..."
\end{tabular}

Similarly, the USS group portrayed M4 metacognitive behaviour and were aware of the mistakes made. However, using the 'trial and error' method did not work for them. Table 15 shows the students' verbal protocol.

Table 15 - Verbal Protocol of Unsuccessful Students

\begin{tabular}{|c|l|}
\hline Participant & \multicolumn{1}{|c|}{ Participant 5 } \\
\hline Verbal Protocol & S16: “Eh wrong!” \\
& S23: "Erm ... Wrong!” \\
& S33: "Erm ... Wrong!” \\
& S44: "Erm... Wrong, wrong. ” \\
& S50: “Wrong!”" \\
\hline & Source: Research Data
\end{tabular}

Meanwhile, Table 16 shows examples of the protocol (cognitive) by USS.

Table 16 - Protocol (Cognitive) of Unsuccessful Students

\begin{tabular}{|c|c|}
\hline Participant & \multicolumn{1}{|c|}{ Participant 5 } \\
\hline Verbal Protocol & S48: "140 minus 102 is equal to 38 ringgit." \\
& S49: "So 100\% times 140 over 38." \\
\hline & Source: Research Data
\end{tabular}




\subsubsection{Identifying new knowledge (M5)}

The SS group did not indicate M5 metacognitive behaviour during the problemsolving process. Students answered the questions without building or delegating new knowledge throughout the problem-solving process. Similarly, the PSS group did not show M5 metacognitive behaviour during the problem-solving process. Although they knew the requirements of the questions, PSS students still had difficulties getting the correct answers. They also could not think of new ideas to help them solve their mathematical problems. On the other hand, we noticed that the USS group demonstrated M5 metacognitive behaviour when answering the questions. For example, they placed an unknown value to get the desired values. Since this method was incorrect, they still failed to get the correct answers. The identified protocol is presented in Table 17.

Table 17 - Verbal Protocol of Unsuccessful Students

\begin{tabular}{|c|c|}
\hline Participant & Participant 5 \\
\hline Verbal Protocol & S17: “35 over 100 times the unknown is \\
equal to 1000." & S18: “Unknown times 1000, times 100 over \\
& 35." \\
\hline & Source: Research Data
\end{tabular}

\subsubsection{Asking relevant questions (Q1)}

The SS group displayed a lack of Q1 metacognitive behaviour during the process of problem-solving. The protocol is illustrated in Table 18.

Table 18 - Verbal Protocol of Successful Students

\begin{tabular}{|c|c|c|}
\hline Participants & Participant 1 & Participant 2 \\
\hline Verbal Protocol & $\begin{array}{c}\text { S16: "What does percentage mean? Try } \\
\text { again... }\end{array}$ & $\begin{array}{c}\text { S1: "What is the percentage of the } \\
\text { balance ... They were not } \\
\text { reinvested?" }\end{array}$ \\
\hline
\end{tabular}

Source: Research Data

In comparison to the SS, the PSS group consistently showed Q1 metacognitive behaviour throughout the problem-solving process. They asked more questions, indicating their lack of confidence in solving the given problem. Table 19 lists examples of the protocol.

Table 19 - Verbal Protocol of Partially Successful Students

\begin{tabular}{|c|c|c|}
\hline Participants & Participant 3 & Participant 4 \\
\hline Verbal Protocol & $\begin{array}{l}\text { S20: "This is a percentage ... } 35 \% \text { times } \\
1000 ? \text { ? } \\
\text { S24: "The total of dividend? The total of } \\
\text { this dividend ..." } \\
\text { S25: "350 in percentage ... } 350 \text { over } \\
\text { 1000, times } 100, \text { right?" }\end{array}$ & S3: "How much is the total dividend?" \\
\hline
\end{tabular}

Source: Research Data 
The USS group often exhibited Q1 metacognitive behaviour during the problemsolving process. They continuously asked similar questions since they did not manage to focus on relevant data in the given question. The protocol is shown in Table 20.

Table 20 - Verbal Protocol of Unsuccessful Students

\begin{tabular}{|c|c|c|}
\hline Participants & Participant 5 & Participant 6 \\
\hline Verbal Protocol & $\begin{array}{c}\text { S15: "If it is one thousand?" } \\
\text { S31: "How much is the percentage ... } \\
\text { that was not reinvested?" }\end{array}$ & $\begin{array}{c}\text { S3: "How much is the percentage that } \\
\text { was not reinvested?" } \\
\text { S11: "What is the percentage of the } \\
\text { balance?" }\end{array}$ \\
& $\begin{array}{c}\text { Show much is the percentage of } \\
\text { the balance... was not } \\
\text { reinvested?" }\end{array}$ & $\begin{array}{c}\text { S12 "What is the percentage of the } \\
\text { balance?" }\end{array}$ \\
\hline
\end{tabular}

Source: Research Data

\subsubsection{Being rhetoric on tasks which are irrelevant with words (N1)}

The data indicated that the SS group occasionally showed N1 metacognitive behaviour. The protocol is illustrated in Table 21 below.

Table 21 - Verbal Protocol of Successful Students

\begin{tabular}{|c|c|c|}
\hline Participants & \multicolumn{1}{|c|}{ Participant 1 } & \multicolumn{1}{c|}{ Participant 2 } \\
\hline Verbal Protocol & S2: “Meaning?" & S2: "Hmmm ... So, how? " \\
\hline
\end{tabular}

Source: Research Data

The PSS group showed moderate N1 metacognitive behaviour throughout the problem-solving process. The protocols are stated in Table 22.

Table 22 - Verbal Protocol of Partially Successful Students

\begin{tabular}{|c|l|}
\hline Participant & \multicolumn{1}{|c|}{ Participant 4 } \\
\hline Verbal Protocol & S2: "How, eh?” \\
& S6: “ASB... investment... How?" \\
& S9: "Is this correct or not, eh?" \\
\hline
\end{tabular}

Source: Research Data

The USS group performed differently from the SS and the PSS groups. They constantly displayed N1 metacognitive behaviour throughout the process of problem-solving. The examples are listed below.

Table 23 - Verbal Protocol of Unsuccessful Students

\begin{tabular}{|l|l|l|}
\hline Participants & \multicolumn{1}{|c|}{ Participant 5 } & \multicolumn{1}{c|}{ Participant 6 } \\
\hline Verbal Protocol & S3: "How to do this?" & S4: "What is this?" \\
& S4: "What kind of question is this?" & S6: "How am I supposed to know?" \\
& S7: "How to answer this?" & \\
& S9: "What question is this?" & \\
& S14: "Percentage of dividend, Oh no! & \\
& S52: "Erm do we calculate this?" How much did I deduct just & \\
& now?" & \\
\hline
\end{tabular}

Source: Research Data 
The metacognitive behaviour demonstrated by the SS, PSS, and USS is summarised in Table 24.

Table 24 - Metacognitive Behaviour of SS, PSS, and USS groups during the Process of PT3 Mathematical Problem-Solving

\begin{tabular}{|c|c|c|c|}
\hline $\begin{array}{l}\text { Metacognitive } \\
\text { Behaviour }\end{array}$ & $\begin{array}{c}\text { Successful Students } \\
\text { (SS) }\end{array}$ & $\begin{array}{c}\text { Partially Successful } \\
\text { Students } \\
\text { (PSS) }\end{array}$ & $\begin{array}{l}\text { Unsuccessful Students } \\
\text { (USS) }\end{array}$ \\
\hline $\begin{array}{c}\text { M1 } \\
\text { Proposing Plans }\end{array}$ & $\begin{array}{c}\text { Showed good M1 } \\
\text { behaviour. }\end{array}$ & $\begin{array}{c}\text { Showed good M1 } \\
\text { behaviour. }\end{array}$ & $\begin{array}{l}\text { Showed M1 behaviour } \\
\text { which unrelated with the } \\
\text { questions' requirements, } \\
\text { and it was clearly wrong. }\end{array}$ \\
\hline $\begin{array}{c}\text { M2 } \\
\text { Identifying the } \\
\text { Level of Question }\end{array}$ & $\begin{array}{l}\text { Did not show M2 } \\
\text { behaviour. }\end{array}$ & $\begin{array}{l}\text { Showed M2 behaviour at } \\
\text { the early stage of the } \\
\text { problem-solving process. }\end{array}$ & $\begin{array}{l}\text { Showed M2 behaviour at } \\
\text { the end of the problem- } \\
\text { solving process. }\end{array}$ \\
\hline $\begin{array}{c}\text { M3 } \\
\text { Re-examining the } \\
\text { Development }\end{array}$ & $\begin{array}{l}\text { Showed M3 behaviour at } \\
\text { the end of the problem- } \\
\text { solving process. }\end{array}$ & $\begin{array}{c}\text { Showed limited M3 } \\
\text { behaviour throughout the } \\
\text { whole problem-solving } \\
\text { process. }\end{array}$ & $\begin{array}{l}\text { Showed M3 behaviour in } \\
\text { the middle and the end of } \\
\text { the problem-solving } \\
\text { process. }\end{array}$ \\
\hline $\begin{array}{c}\text { M4 } \\
\text { Identifying } \\
\text { Mistakes }\end{array}$ & $\begin{array}{c}\text { Showed M4 behaviour } \\
\text { immediately after reaching } \\
\text { a certain solution. }\end{array}$ & $\begin{array}{l}\text { M4 was shown throughout } \\
\text { the whole problem-solving } \\
\text { process, particularly in the } \\
\text { earliest stage. Corrections } \\
\text { were made. However, they } \\
\text { were inaccurate. }\end{array}$ & $\begin{array}{l}\text { M4 behaviour existed, and } \\
\text { the students realised the } \\
\text { mistakes. However, they did } \\
\text { not come out with the } \\
\text { correct answers. }\end{array}$ \\
\hline $\begin{array}{c}\text { M5 } \\
\text { Identifying New } \\
\text { Knowledge }\end{array}$ & $\begin{array}{l}\text { Did not show M5 } \\
\text { behaviour. }\end{array}$ & $\begin{array}{c}\text { Did not show M5 } \\
\text { behaviour. }\end{array}$ & $\begin{array}{l}\text { Showed M5 behaviour. } \\
\text { However, the new } \\
\text { knowledge identified was } \\
\text { wrong and failed to help the } \\
\text { students in solving the } \\
\text { problems. }\end{array}$ \\
\hline $\begin{array}{c}\text { Q1 } \\
\text { Asking Relevant } \\
\text { Questions }\end{array}$ & $\begin{array}{l}\text { Showed limited Q1 } \\
\text { behaviour throughout the } \\
\text { problem-solving process. }\end{array}$ & $\begin{array}{l}\text { Constantly showed Q1 } \\
\text { behaviour throughout the } \\
\text { problem-solving process. }\end{array}$ & $\begin{array}{c}\text { Constantly showed Q1 } \\
\text { behaviour throughout the } \\
\text { problem-solving process. } \\
\text { Similar questions were } \\
\text { asked by students } \\
\text { repeatedly. }\end{array}$ \\
\hline $\begin{array}{c}\mathrm{N} 1 \\
\text { Being Rhetoric } \\
\text { on Tasks that are } \\
\text { Irrelevant with } \\
\text { Words }\end{array}$ & $\begin{array}{l}\text { N1 behaviour existed but } \\
\text { was seldom displayed. }\end{array}$ & $\begin{array}{l}\text { N1 behaviour was } \\
\text { moderately shown. }\end{array}$ & $\begin{array}{l}\text { Constantly showed N1 } \\
\text { behaviour throughout the } \\
\text { problem-solving process. }\end{array}$ \\
\hline
\end{tabular}

Source: Research Data

\section{Discussion}

\subsection{Proposing plans (M1)}

The M1 metacognitive behaviour was the most frequent behaviour exhibited by students in the process of solving PT3 mathematical problems. The SS group exhibited wellorganised metacognitive behaviour, which met the questions' requirements. They dominated 
other groups regarding successfully completing all questions posed to them. Also, M1 metacognitive behaviour of the SS group did not happen all the time, but almost all of their actions were instinctive as they were more knowledgeable and had excellent problem-solving skills. Among the actions related to M1 behaviour were rereading the questions to acquire a deeper understanding of the questions, and extracting relevant content from the questions with a view to plan for a solution. This finding is supported by Elia et al. (2009), who argued that the main determinant of students' ability to successfully solve a problem is the need for them to understand the question's requirements truly.

For the PSS group, M1 metacognitive behaviour in some questions was well-organised similar to the SS group, but for other questions, it was relatively more than the SS and the USS groups. However, their behaviour did not adhere to the questions' requirements. Among the almost similar behaviour with the SS group, were rereading the questions, which usually happened in the middle of the problem-solving process to plan for suitable solutions. However, sometimes their planning did not meet the questions' requirements. The PSS group also extracted relevant information from the questions as they tried to enhance their understanding of the questions. Contrary to these two categories of students, USS showed limited M1 behaviour and it was perceived as incorrect, and it did not meet the questions' requirements. They also demonstrated behaviour which could be related to the M1 behaviour, for example extracting relevant information from the questions. However, this effort was insufficient and only involved parts of the relevant information from the questions. The USS still failed due to several reasons.

i. The students stated that the question required them to find 'percentage of dividends' when the question asked them to find the balance percentage from the total amount of dividends.

ii. Students conducted an incorrect problem-solving procedure.

iii. Students were careless in deduction.

A research conducted by Yeong (2010) regarding the ability and weakness in solving mathematical problem among Form Five students had similar findings with the current research. One of the factors contributing to a low-score in problem-solving was carelessness. The cognitive activities of the USS group were also weak, which further contributed to their failure in solving the PT3 mathematical problems. Kazemi et al. (2010) conducted a study, which main objective was to investigate the role of metacognition in solving mathematical problems. Their findings supported the results of this study. 
i. Students were able to succeed in solving mathematical problems because they felt that some of the processes involved in certain questions occurred automatically.

ii. Although some of the PSS group managed to solve the mathematical problems, these students sometimes encountered difficulties, leading them to make more mistakes.

iii. USS failed to solve mathematical problems because they were too strict in managing the problem-solving process.

Moreover, Abdullah (2009) argued that the strategy of rereading the questions would largely help students to retain better memories and grasp a deeper understanding of any given problems.

\subsection{Identifying the level of question (easy or difficult) (M2)}

This study discovered that M2 metacognitive behaviour was the least metacognitive behaviour applied by students while solving the PT3 mathematical problems. Particularly, the SS group did not show any behaviour related to this domain, and only showed it when solving Question 4 which was the most difficult. It happened when the students were deadlocked and the only protocols uttered by them were "huh..." and "oh no..." The SS group did not show M2 behaviour as they appeared confident in solving the problems without doubts or hesitations. Meanwhile, this particular metacognitive behaviour happened in moderation among the PSS students, and it only took place at the beginning of the problem-solving process. Even though the PSS group stated the level of difficulties faced, they were still able to plan well towards providing a better solution. However, they stated difficulties in answering Question 4 and did not continue to find the solution because they had already given up. Foong (1994) argued that when students failed to solve a particular problem, they would easily become distracted, less confident, and finally give up on completing the given tasks or assignments. Similar to PSS group, the USS students also displayed moderate M2 metacognitive behaviour which only happened at the end of the problem-solving process. After several attempts on solving the problem, they failed to find the accurate solution. Most of the verbal protocol highlighted by them referred to how difficult the question was, indicating that the question was tough. This agreed with Abdullah (2009), who stated that making the right judgement and having positive self-esteem after realising the level of difficulties faced are important in determining the success of a particular problem-solving process. 


\subsection{Re-examining the development (M3)}

The M3 metacognitive behaviour was often presented by the students, mainly among the SS group, and especially at the end of the problem-solving process. This behaviour was shown to check the original and final answer made. The PSS students were found to display limited M3 metacognitive behaviour. They constantly reviewed the progress in the search for a solution, and through this M3 metacognitive behaviour, they were observed to check every solution wisely to avoid any confusion. This finding coincides with the conclusions in Abdullah (2009), whereby the students always unconsciously controlled their problemsolving process to avoid making mistakes. However, the USS group showed M3 metacognitive behaviour more often in the middle of the process of problem-solving, and occasionally in the end. The frequency of this behaviour was exhibited in a limited extent, and the students still made mistakes after they studied the development of the problem-solving process. This finding is supported by Yeong (2010) who found that some students used the right methods, but mistakes still occurred in calculations. One of the reasons was because students applied the wrong formula. This limited frequency of M3 behaviour is supported by the findings of a study conducted by Muir and Beswick (2005). They found that most students did not seem to monitor their progress, think about the appropriateness of their strategies, and did not attempt to use alternative strategies although they were frustrated with their weaknesses. Students were also not able to use alternative methods in reaching the correct answers.

\subsection{Identifying mistakes (M4)}

M4 Metacognitive behaviour is another important aspect of the problem-solving process. If students are unable to identify errors and correct them, their final answers will be affected, and there is a high possibility of getting incorrect answers. Compared to the other groups, the SS students showed this behaviour the most, especially when they first made mistakes at any stage of problem-solving. They tried to fix the problems or mistakes as soon as possible and as a result were able to conclude with the correct answers and solutions. Subsequently, the SS group did not commit many mistakes along the process of PT3 mathematical problem-solving. If there were related problems, the SS group would immediately act to amend the errors. According to Yeong (2010), one of the important factors to ensure that students are successful in solving the problem is for them to be exposed to 
significant experiences and to be equipped with the right strategies in problem-solving skills. The PSS group were relatively more advanced than SS and USS students, as they showed more M4 behaviour throughout the process of problem-solving. When the students realised their mistakes, they would make strategies or discuss with each other to find the correct answers. However, when answering Question 4, although the PSS group had realised their mistakes from the beginning and made corrections, they were still unable to get the correct answer. It was discovered that the students used the trial and error method. This finding is similar to the one discovered by Yeo (2009), who stated that one of the factors why students fail to find the correct and appropriate solution is because they do not have the knowledge of applying suitable solutions to the problems. Students also did not use the correct mathematical operation.

\subsection{Identifying new knowledge (M5)}

Through the analysis of students' answers, the SS group often highlighted M5 metacognitive behaviour. To find the correct values, the students represented the values with unknown values. However, for some questions, the students did not show M5 behaviour because they were more comfortable answering questions without building new knowledge or delegating the problem-solving process. This finding was supported by the findings by Foong (1994), who indicated that students apply the 'identifying new knowledge' behaviour to expect the pattern of given questions. However, for the PSS group, no M5 metacognitive behaviour was found during the process of mathematical problem solving in all four PT3 questions. This could be because the PSS group knew and understood the questions' requirements. However, there were times when they faced difficulties in getting the correct answers. In this case, they were unable to identify new knowledge. Next, the USS students had some similarities with SS group regarding the use of $\mathrm{X}$ and $\mathrm{Y}$ to find the unknown values. However, this behaviour failed to help the USS group, as it was done incorrectly.

\subsection{Asking relevant questions (Q1)}

The SS students highlighted a limited degree of Q1 metacognitive behaviour, and the questions asked were mainly about formulations or strategies that could be used to solve the problems. If compared between the three categories of students, the PSS students were the most frequent group of students who showed Q1 behaviour during the problem-solving 
process. Most of the questions indicated that the students lacked confidence in their knowledge. In contrast, the USS group also showed less Q1 metacognitive behaviour. Even though it existed, there was limited application of this behaviour, and it only happened at the end of the problem-solving process. The questions raised by the USS students were similar and repeatedly asked because they did not focus on the important points in question. Foong (1994) found that unsuccessful students tended to take a relatively long time to construct their self-questioning, and the progress shown by them was still unfocused and wordy. The findings by Abdullah (2009) were consistent with the results of this study, whereby not all students used self-questioning in solving problems, and not all students managed to give the correct answers even after they practised self-questioning in any problem-solving process.

\subsection{Being rhetoric on tasks which are irrelevant with words (N1)}

The SS group portrayed the least N1 metacognitive behaviour during the process of problem-solving as compared to the PSS and USS groups. However, N1 behaviour was seen to occur at the end of the problem-solving process, when students wanted to ascertain whether the provided solutions were correct or not. Moreover, the tendency of N1 metacognitive behaviour to occur at the end of the problem-solving process was because students were unclear and less confident with the solution given. Meanwhile, the PSS students showed N1 metacognitive behaviour in moderation and that often occurred at the middle and end of the problem-solving process. However, it appeared that the questions being asked were focused on how to solve the problems. For the USS group, N1 behaviour was shown throughout the whole process There were many questions asked, and the most popular question was "how to answer this?" which indicated that the students did not know the right solutions to the given problems.

\section{Conclusion}

The study found that each category of students: successful students (SS), partially successful students (PSS), and unsuccessful students (USS) showed different metacognitive behaviour while solving their PT3 mathematical problems. The SS students were able to control their metacognitive behaviour in solving mathematical problems more regularly and frequently than the PSS group, who behaved moderately. The USS students, on the other hand, demonstrated limited metacognitive behaviour. As there are differences in 
metacognitive behaviour, teachers should play their roles by helping students who have weaknesses in solving mathematical problems to use their metacognitive behaviour to overcome the mentioned issues. Also, this research has successfully identified the types of metacognitive behaviour exhibited by students who went through the process of mathematical problem solving.

\section{References}

ABDULLAH, A. H.; IBRAHIM, N. H.; SURIF, J.; ALI, M.; HAMZAH, M. H. Non-routine mathematical problems among in-service and pre-service mathematics teachers. In: 2014 INTERNATIONAL CONFERENCE ON TEACHING, ASSESSMENT AND LEARNING (TALE), IEEE, Proceedings. 2014. p. 18-24.

ABDULLAH, A. H. \& ZAKARIA, E. Enhancing students' level of geometric thinking through van hiele's phase-based learning. Indian Journal of Science and Technology, India, v. 6, n. 5, p. 44324446, 2013.

ABDULLAH, A. H.; RAHMAN, S. N. S. A.; HAMZAH, M. H. Metacognitive Skills of Malaysian Students in Non-Routine Mathematical Problem Solving. Bolema, Rio Claro, v. 31, n. 57, p. 310 322, 2017.

ABDUllah, F. A. P. The Patterns of Physics Problem-Solving from The Perspective of Metacognition. 345 f. Thesis (Doctor of Philosophy) - University of Cambridge, England. 2009.

AHMAD, S.; AZWAWI, T. Isu-Isu Dalam Pendidikan Matematik. 1. ed. Kuala Lumpur. Utusan Publication \& Distributors Sdn. Bhd, 2006. 135 p.

CRISP, V. The Validity of Using Verbal Protocol Analysis To Investigate The Process Involved In Examination Marking. Research in Education, United States, v. 79, p. 1-12, 2008.

EFFANDI Z.; Chin, L. C.; MD. YUSOFF, D. The Effects of Cooperative Learning on Students' Mathematics Achievement and Attitude towards Mathematics. Journal of Social Sciences, Kuwait, v. 6 , n. 2, p. 272-275, 2010.

ELIA, I.; VAN DEN HEUVEL-PANHUIZEN, M.; KOLOVOU, A. Exploring strategy use and strategy flexibility in non-routine problem solving by primary school high achievers in mathematics. International Journal on Mathematics Education, ZDM, Germany, v. 41, n. 5, p. 605-618, 2009.

ERICSSON, K. A.; SIMON, H. A. Verbal reports as data. Psychological review, United States, v. 87, n. 3, p. 215, 1980.

FLAVELL, J. H. Cognitive Development. 4th. ed. New Jersey: Prentice Hall, 2002. 286 p.

FLAVELL, J. H. Metacognitive Aspects of Problem Solving. In: RESNICK, LAUREN B (Ed.). The Nature of Intelligence. Hillsdale: Ed. Lawrence Erlbaum Associates, 1976. p. 233.

FOONG, P. Y. Development of framework for analyzing mathematical problem solving behaviours. Singapore Journal of Education, Singapore, v. 13, n. 1, p. 61-75. 1993.

FOONG, P. Y. Differences in the processes of solving mathematical problems between successful and unsuccessful solvers. Teaching and Learning, United States, v. 14, n. 2, p. 61-72, 1994. 
KAZEMI, F.; FADAEE, M. R.; BAYAT, S. A subtle view to metacognitive aspect of mathematical problem solving. Procedia - Social and Behavioral Sciences, United Kingdom, v. 8, p. 420-426, 2010 .

LAKATOS, I. Proofs and Refutations: The Logic of Mathematical Discovery. 1. ed. Cambridge: Cambridge University Press, 1976. 174 p.

LESH, R.; ZAWOJEWSKI, J. Problem solving and modeling. In: F. K. LESTER J. R. (Ed.). Handbook of Research on Mathematics Teaching and Learning. Reston, VA: NCTM, 2007, p. 763-804.

MUIR, T.; BESWICK, K. Where did I go wrong? Students' success at various stages of the problemsolving process. In: THE 28TH ANNUAL CONFERENCE OF THE MATHEMATICS EDUCATION RESEARCH GROUP OF AUSTRALASIA, Proceeding. Melbourne, Australia, 2005. p. 561-568.

NATIONAL COUNCIL FOR TEACHERS OF MATHEMATICS. Principles and Standards for School Mathematics. 3. ed. Reston, VA: NCTM, 2000. 402 p.

NEWELL, A.; SIMON, H. A. Review: Human problem solving. The American Journal of Psychology, United States, v. 86, n. 2, p. 449-455, 1972.

OTERO, J.; CAMPANARIO, J. M.; HOPKINS, K. D. The relationship between academic achievement and metacognitive comprehension monitoring ability of spanish secondary school students. Educational and Psychological Measurement, United States, v. 52, n. 2, p. 419-430, 1992.

POLYA, G. How To Solve It. 1. ed. Garden City, Ny: Doubleday, 1945. 65 p.

POLYA, G. How to solve it: A new aspect of mathematical method. 2. ed. Stanford University, 1957. $288 \mathrm{p}$.

ROMPAYOM, P. et al. The development of metacognitive inventory to measure students' metacognitive knowledge related to chemical bonding conceptions. In: INTERNATIONAL ASSOCIATION FOR EDUCATIONAL ASSESSMENT (IAEA) 2010. Proceedings. Bangkok: Srinakharinwirot University, 2010. p. 1-7.

SCHOENFELD, A. H. Mathematical Problem Solving. 1. ed. Hillsdale: Lawrence Erlbaum Associates, 1985. 409 p.

TRAININ, G.; SWANSON, H. L. Cognition, metacognition, and achievement of college students with learning disabilities. Learning Disability Quarterly, United States, v. 28, n. 4, p. 261-272, 2005.

VRUGT, A.; OORT, F. J. Metacognition, achievement goals, study strategies and academic achievement: pathways to achievement. Metacognition and Learning, United States, v. 30, n. 5, p. 123-146, 2008.

WONG, W. Y.; ABDULLAH, F. A. P. Level of awareness on low carbon society concept among secondary school students. In: Education Postgraduate Research Seminar (EDUPRESS) 2010. Proceedings. Malaysia: Universiti Teknologi Malaysia, 2011. p. 41-55.

YEO, K. K. J. Secondary 2 students' difficulties in solving non-routine problems. International Journal for Mathematics Teaching and Learning, United Kingdom, v. 8,1-p. 30, 2009 
YEONG, W. C. Keupayaan dan Kelemahan Menyelesaikan Masalah Matematik Dalam

Kalangan Pelajar Tingkatan Lima. 189 f. Research Project (Undergraduate) - Fakulti Pendidikan.

Universiti Teknologi Malaysia. 2010.

ZAIDATUN, T. Hubungan Antara Persepsi Pelajar Terhadap Matematik Dengan Tahap Kemahiran Metakognitif Dalam Menyelesaikan Masalah Matematik. 1. ed. Skudai : Penerbit Universiti Teknologi Malaysia, 2007. 115 p.

Submetido em 20 de Junho de 2016. Aprovado em 21 de Outubro de 2016. 